\title{
Recent advances in the pathology of prodromal non-motor symptoms olfactory deficit and depression in Parkinson's disease: clues to early diagnosis and effective treatment
}

\author{
Yeojin Bang ${ }^{1} \cdot \mathrm{Juhee}^{\mathrm{Lim}^{2}} \cdot$ Hyun Jin Choi ${ }^{1}$
}

Received: 10 March 2021 / Accepted: 1 June 2021 / Published online: 19 June 2021

(C) The Author(s) 2021

\begin{abstract}
Parkinson's disease (PD) is a progressive neurodegenerative disease characterized by movement dysfunction due to selective degeneration of dopaminergic neurons in the substantia nigra pars compacta. Non-motor symptoms of PD (e.g., sensory dysfunction, sleep disturbance, constipation, neuropsychiatric symptoms) precede motor symptoms, appear at all stages, and impact the quality of life, but they frequently go unrecognized and remain untreated. Even when identified, traditional dopamine replacement therapies have little effect. We discuss here the pathology of two PD-associated non-motor symptoms: olfactory dysfunction and depression. Olfactory dysfunction is one of the earliest non-motor symptoms in PD and predates the onset of motor symptoms. It is accompanied by early deposition of Lewy pathology and neurotransmitter alterations. Because of the correlation between olfactory dysfunction and an increased risk of progression to $\mathrm{PD}$, olfactory testing can potentially be a specific diagnostic marker of $P D$ in the prodromal stage. Depression is a prevalent PD-associated symptom and is often associated with reduced quality of life. Although the pathophysiology of depression in PD is unclear, studies suggest a causal relationship with abnormal neurotransmission and abnormal adult neurogenesis. Here, we summarize recent progress in the pathology of the nonmotor symptoms of $\mathrm{PD}$, aiming to provide better guidance for its effective management.
\end{abstract}

Hyun Jin Choi

hjchoi3@cha.ac.kr

1 College of Pharmacy and Institute of Pharmaceutical Sciences, CHA University, Pocheon, Gyeonggi-do 11160, Republic of Korea

2 College of Pharmacy, Woosuk University, Wanju, Jeollabuk-do 55338, Republic of Korea
Keywords Depression $\cdot$ Hyposmia $\cdot$ Neurogenesis $\cdot$ Nonmotor $\cdot$ Parkinson's disease

\section{Introduction}

Parkinson's disease (PD) is a progressive neurological disorder characterized by motor dysfunction that affects 10 million people globally, and this number is expected to double by 2030 (Dorsey et al. 2007). Many non-motor PD symptoms, including loss of smell, sleep disorders, depression, and constipation, can precede motor symptoms by several years. Dopamine replacement strategies are widely used for symptomatic therapy for PD as they improve key motor symptoms including bradykinesia, rigidity, and tremor. However, non-motor symptoms usually do not respond to motor deficits-targeting dopamine replacement therapy (Ray Chaudhuri et al. 2018; Deuel and Seeberger 2020). Leaving non-motor symptoms untreated can lead to a poor disease prognosis and a negative effect on the quality of life of patients with PD (Sauerbier et al. 2016). Although dopaminergic pathology is the cardinal feature in the brains of patients with PD, a more diffuse pathology might be associated with non-motor symptoms as well; the cholinergic glutamatergic, noradrenergic, and serotonergic systems (Brandão et al. 2020). Therefore, understanding the pathology of PD's non-motor symptoms and ensuring an early and accurate diagnosis and an appropriate therapeutic approach in the PD prodromal stage remains a major and challenging goal for PD treatment. Using neuropathological PD findings as gold standard, the accuracy for a PD clinical diagnosis was only $26 \%$ in untreated or not clearly medication-responsive subjects, and $53 \%$ in early PD patients $(<5$ year's duration) responsive to medication (Adler et al. 2014). 
The olfactory deficit shows high prevalence in patients with PD, early and easy diagnosis, and persistence throughout the disease course. Olfactory dysfunction has a prevalence $>90 \%$ in patients with PD and is a potential preclinical biomarker and a cardinal prodromal symptom that may precede neuropathology (Bohnen et al. 2008b; Shill et al. 2021). Although a correlation between olfactory dysfunction and neurodegenerative disorders has been increasingly recognized (Bahuleyan and Singh 2012), the underlying mechanism is not completely understood.

Depression is a nonspecific symptom, but the most common psychiatric symptom in PD, occurring in over one-third of cases. Depression may be present throughout all PD stages. For instance, at disease onset, up to $40 \%$ of patients with PD experience depression, whereas in the advanced stage, up to $70 \%$ of patients will have presented with depressive symptoms (Aarsland et al. 2009). Additional research has shown that the average onset of depressive symptom was 17.6 years earlier than the average age at PD diagnosis (Seritan et al. 2019). If PD onset could be recognized early, disease progression could be slowed by initiating appropriate neuroprotective treatment at the most effective stage. Depression could be one of the effective clinical markers of prodromal PD (Hustad and Aasly 2020), but the pathophysiology of depression in PD remains poorly understood. In the present review, we summarize the current progress in two pathological features of PD-olfactory deficits and depression-to provide crucial insights into the requirements of early diagnosis and clearer recommendations for PD treatment.

\section{Olfactory dysfunction}

Hyposmia is one of the characteristic non-motor signs of early PD, which may occur early, before the onset of motor disorders (Fig. 1). Clinical and experimental evidence suggest pathological changes in the olfactory bulb (OB), such as formation of pathological protein aggregates and changes in neurotransmitter signaling, at relatively early stages of $\mathrm{PD}$, suggesting that olfaction may be vulnerable from early stages of PD progression (Table 1) (Rey et al. 2018). Olfactory dysfunction is correlated with disease progression and cognitive decline in PD (Domellöf et al. 2017; Cecchini et al. 2019). Furthermore, the effective levodopa dose is higher in patients with PD with hyposmia than in patients with normosmia (He et al. 2020). Therefore, detection of olfactory impairment could be useful for accurate PD diagnosis in the prodromal stage and for predicting disease progression risk.

\section{Olfactory ability and olfactory atrophy in PD}

Patients with PD are often unaware of their olfactory deficit before testing. Less than $25 \%$ of patients with olfactory disturbance seem to realize their problem prior to diagnosis (Schmidt et al. 2020). Some patients with PD misestimate their own olfactory function as better than their actual odor identification ability (Leonhardt et al. 2019). Olfactory disturbance negatively affects the quality of life, by impacting the enjoyment of food, mood, and social interaction (Frasnelli and Hummel 2005; Vassilaki et al. 2017). Olfactory function is typically measured in a clinical setting by odor discrimination, odor identification, and odor detection threshold tasks (Fullard et al. 2017). The most frequently used and well-characterized method for olfaction assessment

\begin{tabular}{|c|c|c|c|}
\hline \multicolumn{4}{|c|}{ Diagnosis } \\
\hline \multirow[t]{3}{*}{ Braak stagging } & $1 \sim 2$ & $3 \sim 4$ & $5 \sim 6$ \\
\hline & \multicolumn{3}{|c|}{ Progression of PD } \\
\hline & Prodromal-Early stage & Mid stage & Late stage \\
\hline Lewy pathology & $\begin{array}{l}\text { - Peripheral autonomic neurons } \\
\text { - Medulla oblongata } \\
\text { - Olfactory bulb } \\
\end{array}$ & $\begin{array}{l}\text { - Midbrain substantia nigra; } \\
\text { - Amygdala } \\
\text { - Nucleus bailis of Meynert }\end{array}$ & - Cerebral cortex \\
\hline \multirow[t]{2}{*}{ Symptom } & $\begin{array}{l}\text { - Hyposmia/anosmia } \\
\text { - REM sleep behavior disorder } \\
\text { - Constipation } \\
\text { - Anxiety } \\
\text { - Depression } \\
\text { - Cognitive change } \\
\text { - Subtle motor impairment }\end{array}$ & $\begin{array}{l}\text { - Bradykinesia, Rigidity, Tremor } \\
\text { - Dysphagia } \\
\text { - Sleep disturbance }\end{array}$ & $\begin{array}{l}\text { - Dementia } \\
\text { - Cognitive dysfunction } \\
\text { - Hallucinations } \\
\text { - Incontinence } \\
\text { - Sexual dysfunction } \\
\text { - Orthostatic hypotension }\end{array}$ \\
\hline & Nonmotor symptoms & Motor symptoms & \\
\hline
\end{tabular}

Fig. 1 Timeline of Parkinson's disease 


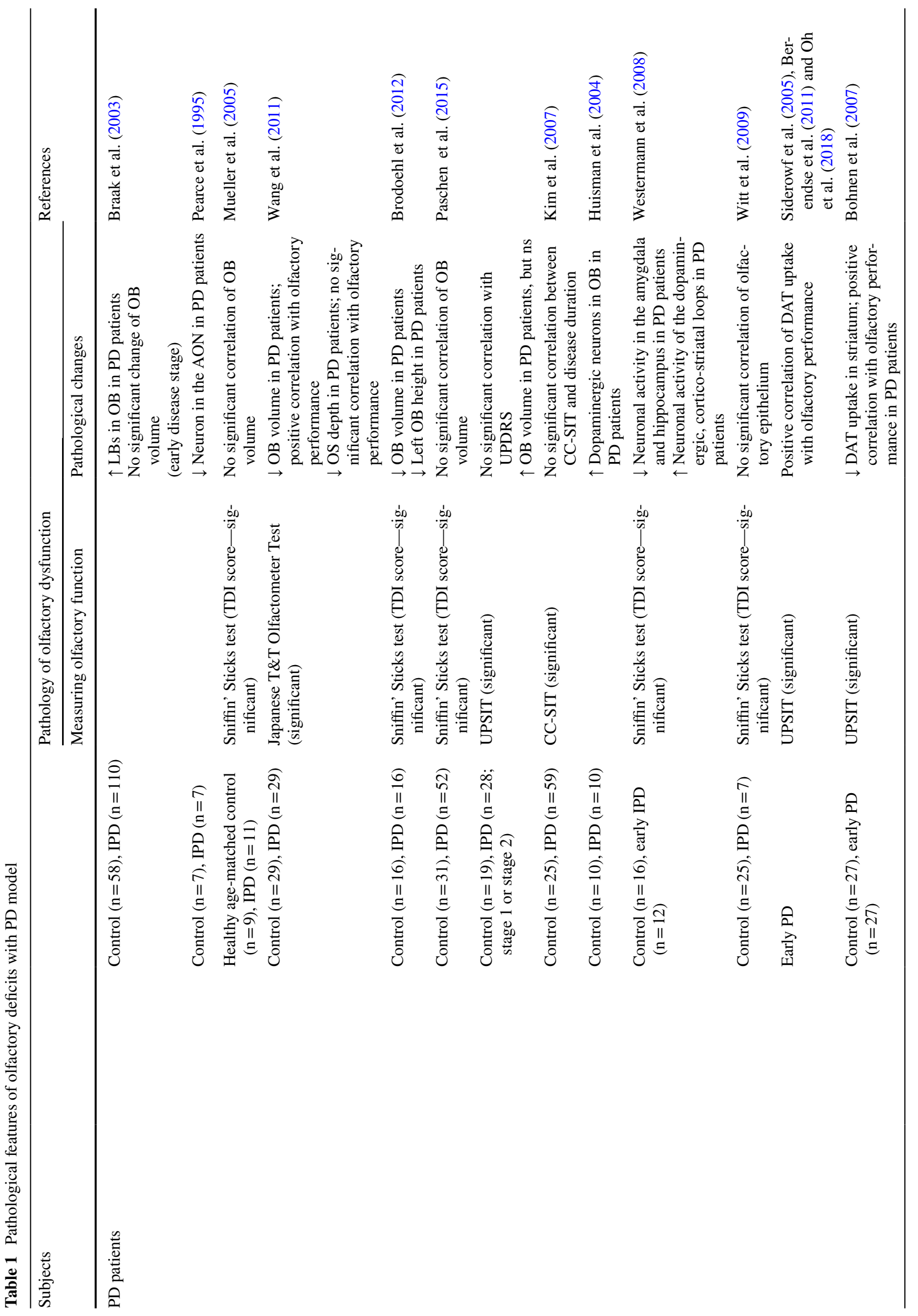




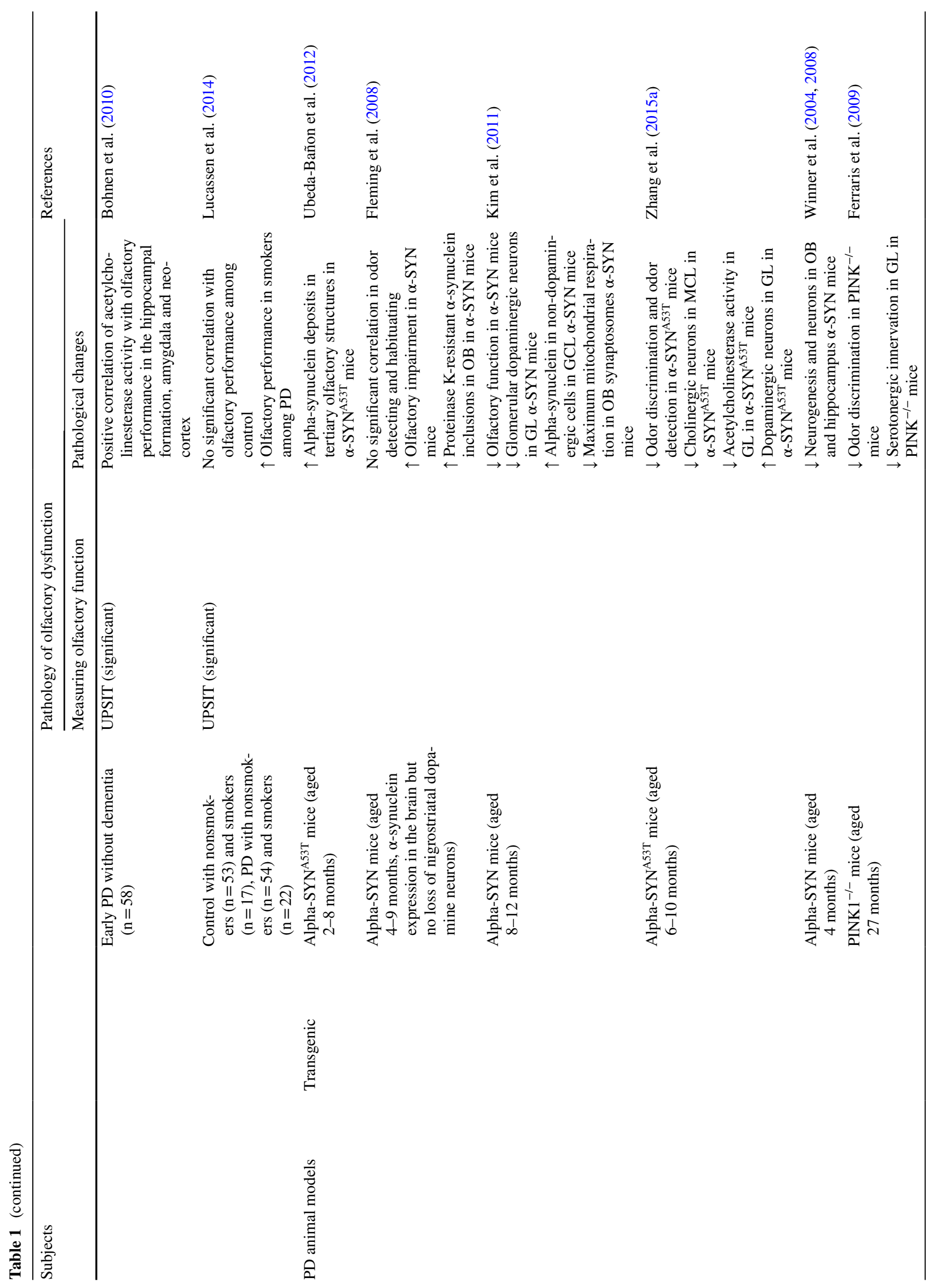




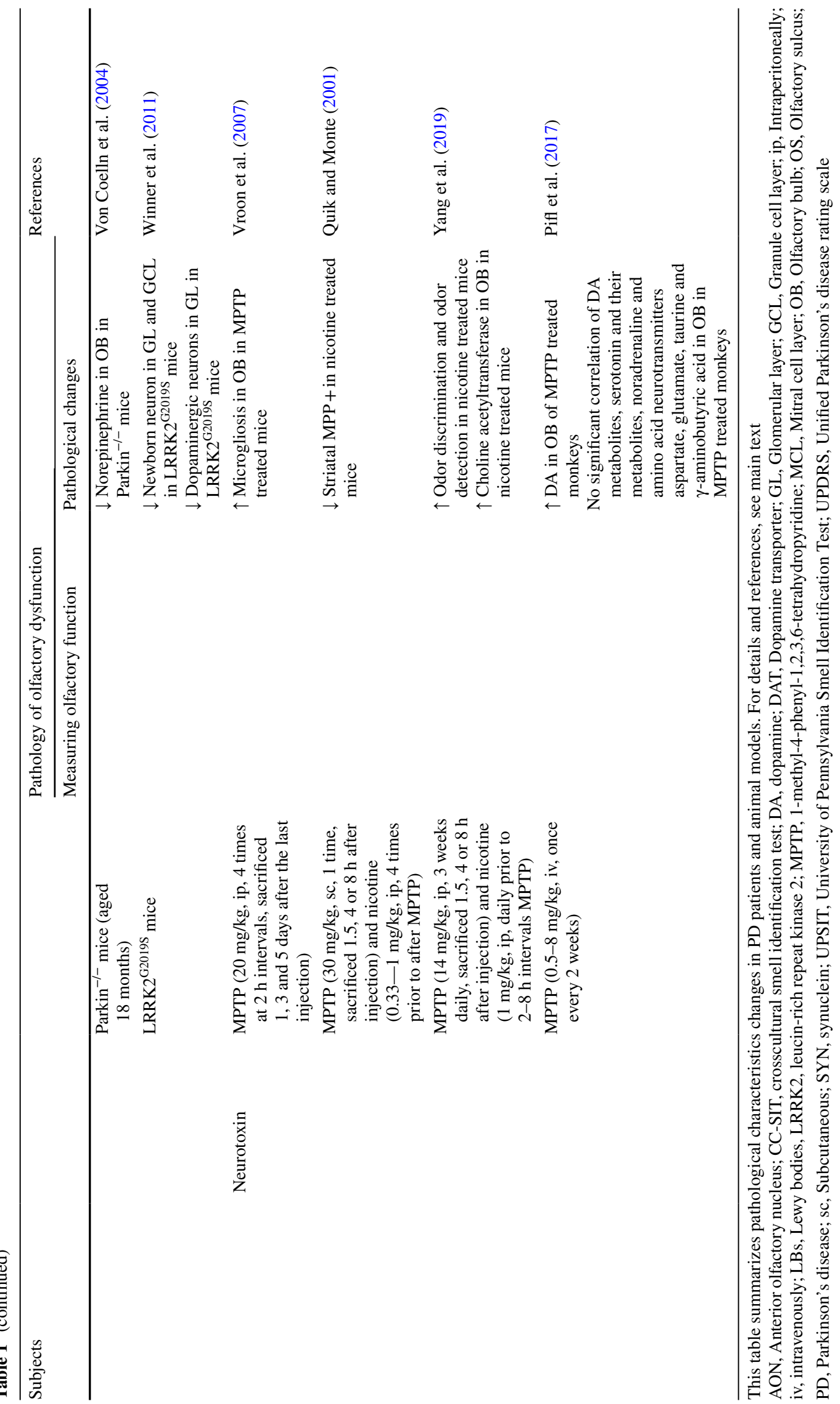


is odor identification by the University of Pennsylvania Smell identification Test (UPSIT), which includes 40 microencapsulated odorous substances presented in a "scratch ' $n$ ' sniff" booklet (Doty et al. 1984). Other olfactory performance clinical tests, such as odor detection threshold tests (e.g., Smell Threshold Test or Connecticut Chemosensory Clinical Research Center Test), can be used in combination with the UPSIT (Fullard et al. 2017). The UPSIT scores of PD were strongly correlated with various motor and non-motor symptoms, such as anxiety, depression and sleep disturbances, as well as with the degree of nigrostriatal dopaminergic cell loss, indicating that olfactory assessment using UPSIT could be a potential diagnostic tool for predicting disease progression. (Roos et al. 2019). In a few cases, olfactory deficits have also been reported in patients with familial PD (Liu et al. 2020b). Monogenic PD patients with mutations in the genes leucine-rich repeat kinase 2 (LRRK2) (Khan et al. 2005; Healy et al. 2008), PTEN-induced putative kinase 1 (PINK1) (Ferraris et al. 2009), vacuolar protein sorting 35 (VPS35) (Struhal et al. 2014), glucocerebrosidase (GBA) (Alcalay et al. 2012) showed similar changes in UPSIT scores to those with idiopathic PD, but patients with Parkin (Khan et al. 2004; Malek et al. 2016) mutations showed normal olfactory function.

The pathological relationship between olfactory deficit and decreased OB volume in PD is controversial. When analyzed using the MRI and the Japanese T\&T olfactometer threshold test, the olfactory performance positively correlated with $\mathrm{OB}$ volumes in both patients with PD and controls (Wang et al. 2011). In patients with early stage PD, olfactory performance is positively correlated with $\mathrm{OB}$ volume, but not with the olfactory sulcus depth (Wang et al. 2011). Table 1 summarized other reports on the correlation between olfaction and $\mathrm{OB}$ volume in patients with $\mathrm{PD}$. In idiopathic $\mathrm{PD}$ cases, the $\mathrm{OB}$ volume on 3-T magnetic resonance imaging (MRI) did not differ from that of healthy age-matched controls (Paschen et al. 2015). Although the UPSIT scores were significantly lower in stage 1 and 2 patients than in controls, no statistically significant difference was observed in OB volumes between PD and control groups (Hakyemez et al. 2013). Further, olfactory biopsy results of patients with PD showed no significant changes in the olfactory epithelium between patients with PD and controls (Witt et al. 2009), suggesting that olfactory deficits in PD could be due to abnormal olfactory brain transmission rather than structural damage to the olfactory system.

\section{Lewy pathology in the olfactory system in PD}

Lewy pathology in the OB was detected in $95 \%$ of patients with PD and in 7\% of elderly controls without parkinsonism diagnoses (Beach et al. 2009). In the brain of PD patients, immunoreactive Lewy bodies and Lewy neurites, which affect the olfactory system, are detected in the OB and dorsal glossopharyngeus-vagus complex even at very early stages (Gustavsson et al. 2020). These deposits spread to the brainstem including medulla and pontine tegmentum (Hawkes et al. 2010), and reach the substantia nigra in Braak stage 3, whereupon the typical motor symptoms of PD begin (Fearnley and Lees 1991). This aberrant deposit accumulation shows varying degrees of severity among neurodegenerative diseases. In postmortem tests in the olfactory region, tau-related pathology has been found in patients with Alzheimer's disease, PD, Lewy bodies dementia, and frontotemporal dementia. However, tau-related pathology is not detected in patients with progressive supranuclear palsy or corticobasal degeneration with less olfaction loss (Doty 2017). A study on $\alpha$-synucleinopathy in the olfactory system detected higher immunoreactivity against $\alpha$-synuclein in the different divisions of the olfactory system in patients with PD (Braak stages 3-5) than age-matched controls. Although motor dysfunction in PD is primarily associated with the pathology in dopaminergic neurons in the nigrostriatal pathway, $\alpha$-synucleinopathy along the olfactory pathway was rarely detected in dopaminergic cells, but rather in glutamate-, calcium-binding protein- and substance P-positive cells (Ubeda-Bañon et al. 2010).

\section{Changes in neurotransmitter signaling in PD-associated olfactory dysfunction}

It has been demonstrated that alteration of neurotransmitters is associated with hyposmia in PD. Marked decreases in the numbers and activity of cholinergic neurons in the mitral cell layer and increases in dopaminergic neuron numbers and TH protein levels in the glomerular layer were reported in $\alpha$-synuclein A53T transgenic mice compared to wild-type littermates (Zhang et al. 2015a). A significant increase in dopamine levels is also shown in the OB of 1-methyl-4-phenyl-1,2,3,6-tetrahydropyridine (MPTP)-induced monkey PD model (Pifl et al. 2017) without changes in other monoamine neurotransmitters. However, a decrease in norepinephrine level was detected in the OB in Parkin null mice (Von Coelln et al. 2004). In Pink1 null mice, damage to the serotonergic innervation in the olfactory glomerular layer was reported, along with an impaired fine-tuning of the smell identification function (Ferraris et al. 2009). In this section, we focus on dopamine and acetylcholine signals, the most reported neurotransmitters related to olfactory abnormalities in PD.

\section{Dopaminergic signaling}

The OB glomerular layer contains up to $10 \%$ dopaminergic interneurons (Fig. 2), which participate in olfactory processes such as perception, discrimination, and 


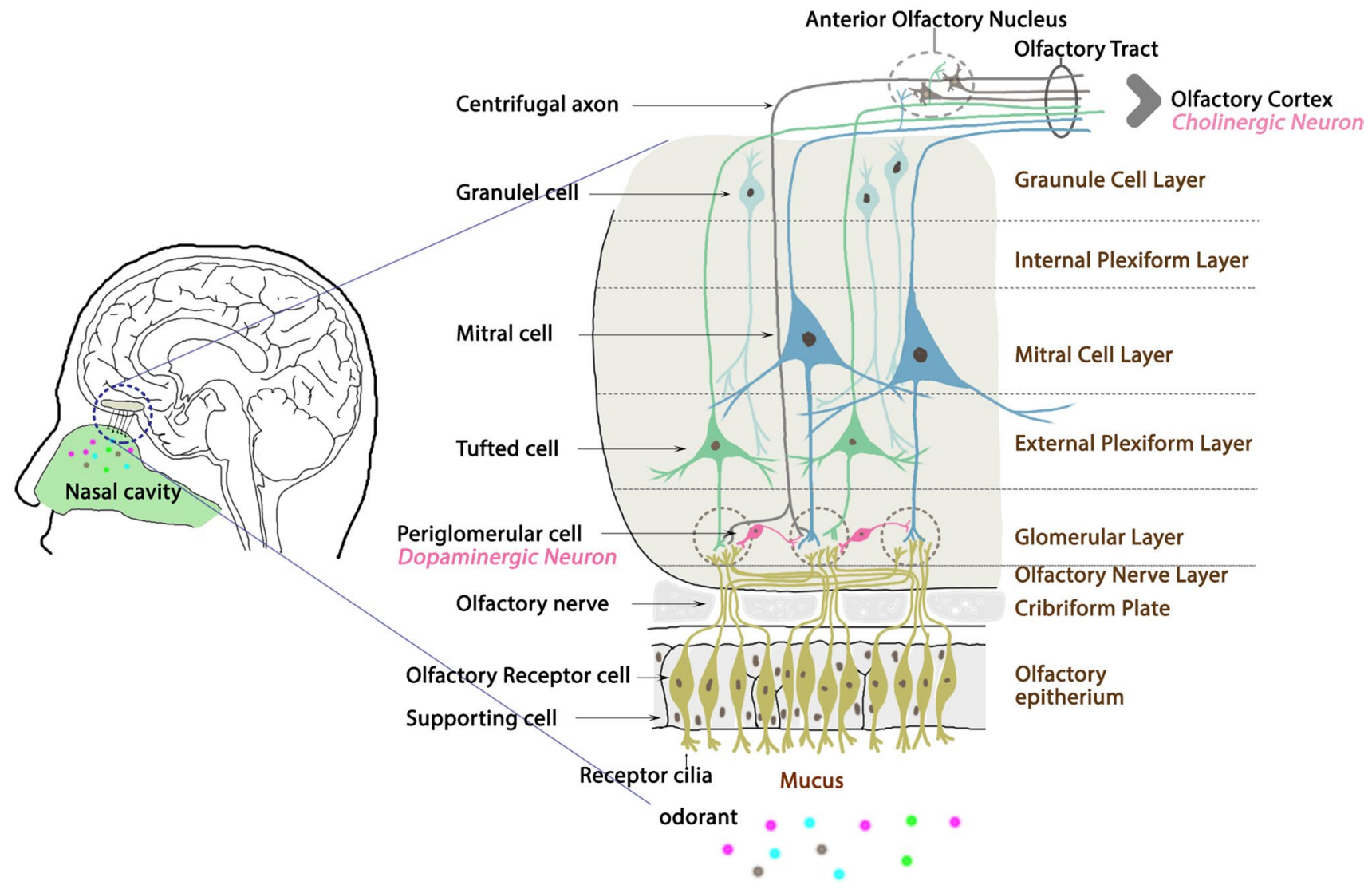

Fig. 2 Schematic of the olfactory bulb (OB) showing the major cell types and the synaptic interaction. Note that dopamine modulates the membrane potential of the bulbar mitral cells through D2 dopamine receptors, which restrict the entry of the perceived olfactory input. The presynaptic D2 receptor functions in processing odor information and adapting the bulbar network to external stimuli

olfaction-guided social interactions (Tillerson et al. 2006; Marin et al. 2017). Dopamine modulates olfactory transmission in the olfactory glomerular layer (Liu et al. 2020a) and has inhibitory regulation through D2 dopamine receptors in processing synaptic inputs from olfactory sensory neurons to mitral cells in the OB (Duchamp-Viret et al. 1997; Hsia et al. 1999; Berkowicz and Trombley 2000). In vitro studies show that activation of presynaptic D2 receptor inhibits excitatory glutamatergic transmission between mitral/tufted cells and interneurons, an effect mainly mediated by inhibition of calcium channels (Davila et al. 2003; Gutièrrez-Mecinas et al. 2005). The numbers and firing rates of dopaminergic periglomerular neurons in the OB are higher in patients with PD than age-matched controls; tyrosine hydroxylase (TH) immunoreactivity in the $\mathrm{OB}$ is twice as high in patients with PD than in controls (Huisman et al. 2004). Further, the olfactory impairment in PD is not responsive to dopamine replacement therapy (Huisman et al. 2004; Haehner et al. 2011). Therefore, the PD-associated dopamine alteration in the OB seems to have a pathological mechanism different from that of the PD-associated dopaminergic neurodegeneration in the nigrostriatal pathway; it may be a compensatory mechanism triggered by early degeneration of other neurotransmitter systems (Mundiñano et al. 2011).

For differential diagnosis of PD, dopamine transporter (DAT) imaging is useful. Substantial evidence shows the close correlation between abnormal DAT binding and olfactory deficits in early PD (Bohnen et al. 2007; Berendse et al. 2011). The level of DAT uptake is significantly reduced in the bilateral caudate and left anterior and posterior putamen in patients with PD with hyposmia compared to patients with normosmia (Oh et al. 2018). DAT positron emission tomography (PET) shows a difference in correlation coefficients between olfactory testing score and DAT binding potential depending on the brain region; with a higher correlation for the hippocampus than the amygdala, ventral and dorsal striatum (Bohnen et al. 2008a). These findings suggest that dopaminergic impairment in regions other than the $\mathrm{OB}$ could be responsible for the olfactory dysfunction observed in patients with PD. 


\section{Cholinergic signaling}

The OB receives several neuromodulatory signals, including central cholinergic transmission. Cholinergic signals from the basal forebrain regulate neuronal activity within the OB, thus modulating olfactory function (D'souza and Vijayaraghavan 2014), further contributing to olfactory perceptual learning, odor discrimination, and odor detection (Mandairon et al. 2006; Chaudhury et al. 2009). Evidences have shown that dysregulated cholinergic neurotransmission is associated with olfactory loss in PD (Perez-Lloret and Barrantes 2016). Although the underlying mechanisms by which acetylcholine modulates neuronal excitability in OB and olfactory responses are not well understood, a substantial correlation exists between UPSIT scores and acetylcholinesterase activity in patients with PD. A cholinergic deficit occurs in the limbic archicortex of PD patients without dementia and is associated with olfactory dysfunction (Bohnen et al. 2010). This relationship is stronger than that with dopaminergic denervation in the nigrostriatal pathway. Moreover, several animal studies have demonstrated that cholinergic system disruption could cause impaired odor discrimination. Blocking nicotinic receptors in the $\mathrm{OB}$ of cannulated rats showed decreased spontaneous discrimination of chemically related odorants (Mandairon et al. 2006), and also cholinergic OB innervation was reduced in MPTP-monkeys compared to control animals. Further, MPTP decreased dopaminergic innervation and cholinergic neurons in the horizontal limb of the diagonal band of Broca, the nucleus where cholinergic centrifugal projections to the $\mathrm{OB}$ originate (Mundinano et al. 2013). OB glomeruli contain high concentrations of nicotinic acetylcholine receptors and receive strong cholinergic innervation from the basal forebrain (Ma and Luo 2012). Retrospective studies highlight nicotine's potential to improve olfactory function in PD patients (Quik and Monte 2001; Quik et al. 2008; Nicholatos et al. 2018): among PD patients, smokers scored higher on the UPSIT than non-smokers (Lucassen et al. 2014). The ameliorative effect of nicotine on olfactory dysfunction is also shown in the MPTP-induced PD mouse model. Nicotine attenuated the deficit in odor discrimination and detection, the loss of choline acetyltransferase expression in the $\mathrm{OB}$, and the loss of cholinergic neurons and dopaminergic input in the horizontal limb of the diagonal band in MPTP-treated mouse brains (Yang et al. 2019).

\section{Decreased olfactory neurogenesis in PD-associated hyposmia}

Adult neurogenesis occurs primarily in the subventricular zone (SVZ) of the lateral ventricles and the sub granular zone of the hippocampus (Lois and Alvarez-Buylla 1993; Palmer et al. 1997). Newborn neuronal precursors generated in the adult SVZ migrate toward the OB via the rostral migratory stream (RMS), and differentiate into GABAergic and dopaminergic granule and periglomerular interneurons. In the olfactory epithelium, the number of basal stem cells decreases with age, associated with a deterioration of olfaction (Rebholz et al. 2020). Disruption of adult neurogenesis in the SVZ may contribute to diverse pathological states such as decreased neuronal plasticity, olfactory deficits, and/ or cognitive dysfunction in the PD brain (Marchetti et al. 2020). BrdU-positive newborn neurons in the OB were reduced in the adult mouse brain overexpressing wild-type or mutant $\alpha$-synuclein (Winner et al. 2004; Winner et al. 2008). Delayed neural stem cell migration through the SVZ/ RMS/OB system and reduced neural stem cell survival is observed in the OB of human- $\alpha$-synuclein transgenic mice (Winner et al. 2004; Tani et al. 2010). Mice overexpressing the PD-related mutant protein G2019S LRRK2 also display a significant decrease in the neurogenesis of dopaminergic (TH, BrdU, and NeuN positive) neurons, as well as a reduced survival of newborn neurons in the OB (Winner et al. 2011). In contrast, the number of BrdU-positive cells in the OB granule cell layer decreased in the brains of 6-hydroxydopamine-lesioned adult rats, but dopaminergic neurogenesis increased in the glomerular layer after lesioning (Winner et al. 2006).

\section{Clinical significance of olfactory dysfunction: biomarker for early PD}

Because of its early appearance, high prevalence and easy and inexpensive assessment, olfactory dysfunction in PD could be a good early biomarker for PD. In addition, the measurement of olfactory deficits has great potential for augmenting diagnostic accuracy and distinguishing idiopathic PD from other diseases such as essential tremor, parkinsonism-associated tauopathies, atypical parkinsonian syndromes, and drug-induced parkinsonism at early stages of the disease (Ponsen et al. 2004; Baba et al. 2011; Doty 2012; Elhassanien et al. 2021).

\section{Depression}

Depression is the most prevalent non-motor psychiatric symptom in people with PD. More than $40 \%$ of individuals with PD have symptoms of depression (Todorova et al. 2014). It has been reported that monogenic PD patients with mutations in the $\alpha$-synuclein, LRRK2, VPS35, Parkin, PINK1, DJ-1 and GBA genes exhibit psychiatric disturbances such as depression and anxiety (Liu et al. 2020b). In particular, PD patients carrying parkin, PINK1 and GBA mutations have more severe depression compared with idiopathic PD (Ephraty et al. 2007; Thaler 
et al. 2018; Zhou et al. 2020). Currently, there are no guidelines or recommendations for selective treatment of depression associated with PD, so patients with PD are not receiving the optimal treatment for depression (Weintraub et al. 2003). Here, we would like to summarize the current knowledge of depression pathophysiology in PD (Table 2) to provide appropriate therapeutic strategies.

\section{Neurotransmitter alterations in depression associated with PD}

Changes in neurotransmitter systems appear before dopaminergic neurodegeneration and influence the development of non-motor symptoms. PET showed lower DAT availability in striatal and limbic structures is related to depression in PD (Remy et al. 2005; Rektorova et al. 2008). In addition, the severity of depression in patients with PD and dysfunctional mesocorticolimbic dopaminergic transmission are correlated (Wei et al. 2018). Further, the dopamine level in cerebrospinal fluid was significantly lower in depression with PD patients than in non-depressed patients with PD (Lian et al. 2018). In addition, in depressed patients with PD, pathological processes in the serotonergic neuronal system, such as changes in the serotonin transporter (SERT), appeared prior to lesions in dopaminergic midbrain neurons (Pagano et al. 2017). Higher SERT levels resulted in worsening depressive symptoms, and increased SERT binding in raphe nuclei and limbic structures were found in PD patients with depression compared to those without depressive symptoms (Boileau et al. 2008; Politis et al. 2010). Reduced concentrations of plasma serotonin (5-hydroxytryptamine, 5-HT) and its metabolite 5-hydroxyindoleacetic acid (5-HIAA) also correlated with the severity of depression in PD (Tong et al. 2015). In addition, depressed patients with PD presented reductions in acetylcholine receptor binding in the cortex (Meyer et al. 2009).

Depressive behavior and abnormal neurotransmission are shown in PD animal models: both in neurotoxin-based models that induce dopaminergic neurodegeneration, and genetic models associated with mutations in PD-related genes (Blesa et al. 2012). Lesions of the nigrostriatal pathway induced by 6-hydroxydopamine (6-OHDA) cause depression-like behavioral changes similar to the premotor symptoms of PD. In this model, the striatal contents of dopamine, dopamine metabolite dihydroxyphenylacetic acid (DOPAC), 5-HT, and 5-HIAA, were all decreased (Silva et al. 2016). Another neurotoxin, MPTP, also increases depression-like behavior and decreases TH expression (Zhang et al. 2016; Yan et al. 2020). Further, upregulation of monoamine oxidase A (MAO-A) and a decrease in noradrenaline and 5-HT in hippocampus were shown in the brain of a-synuclein A53T transgenic mice (Li et al. 2020a). In the LRRK2-G2019S PD mice model, anxiety/depression-like behavior was observed before the onset of motor dysfunction, accompanied by upregulation of the serotonin $5-\mathrm{HT}_{1 \mathrm{~A}}$ receptor (Lim et al. 2018b). The monoamine oxidase-B (MAO-B) inhibitor selegiline significantly ameliorated depressive behavior (immobility time in the forced swim test) and restored reduced striatal 5-HT, cortical norepinephrine, and plasma corticosterone in CD157 knockout mice (Kasai et al. 2017). These findings suggest that impaired monoaminergic neurotransmission contributes to depression in PD, but the current findings do not explain all pathologies in depressed patients with PD.

\section{Altered neuroplasticity and neurogenesis in the PD brain}

In addition to theories focusing on neurotransmitters, theories of neuroplasticity and neurogenesis have been advanced to overcome the limitations of the monoamine hypothesis. These are the leading alternate hypotheses: meta-analyses of MRI studies have shown reductions in hippocampal volume in depressed patients relative to healthy subjects (Videbech and Ravnkilde 2004). To explain why hippocampal volume decreased in depressed patients, we summarize the neuroplasticity hypothesis by focusing on morphological changes such as shortened dendrites and decreased spine number and density, and the neurogenesis hypothesis by focusing on decreased hippocampal neurogenesis.

Some monoaminergic antidepressants improve synaptic plasticity at several levels, such as alteration of brain-derived neurotrophic factor (BDNF) expression and regulation of synapse formation (Björkholm et al. 2016). BDNF is a wellknown growth factor that acts as an essential antidepressant. BDNF binds with high affinity to the tropomycin receptor kinase B (TrkB) receptor; BDNF-TrkB signaling can regulate neurotransmission and enhance synaptic efficacy as well as neuronal differentiation, maintenance, survival and regeneration (Cohen-Cory et al. 2010; Park and Poo 2013). A microarray study showed decreased BDNF and TrkB expression in postmortem brains of depressed patients (Guilloux et al. 2012). Moreover, BDNF serum levels were decreased in patients with PD (Jiang et al. 2019). Consistent with these findings, some studies have shown that the therapeutic effect of PD is associated with BDNF enhancement. An increase in BDNF levels was accompanied by a favorable response to dopamine $\mathrm{D}_{3}$ receptor agonists, significantly improving behavioral performance and attenuating dopaminergic neuronal loss in an animal model of PD ( $\mathrm{Li}$ et al. 2010). Moreover, MAO-B inhibitors, (-) deprenyl and rasagiline, increased neurotrophic factor levels in the cerebrospinal fluid of patients with PD (Naoi and Maruyama 2009). A negative association was found between BDNF plasma levels and severity of anxiety and depression (HAM-A and HAM-D scores) (Costa et al. 2019; Yang et al. 2020). 


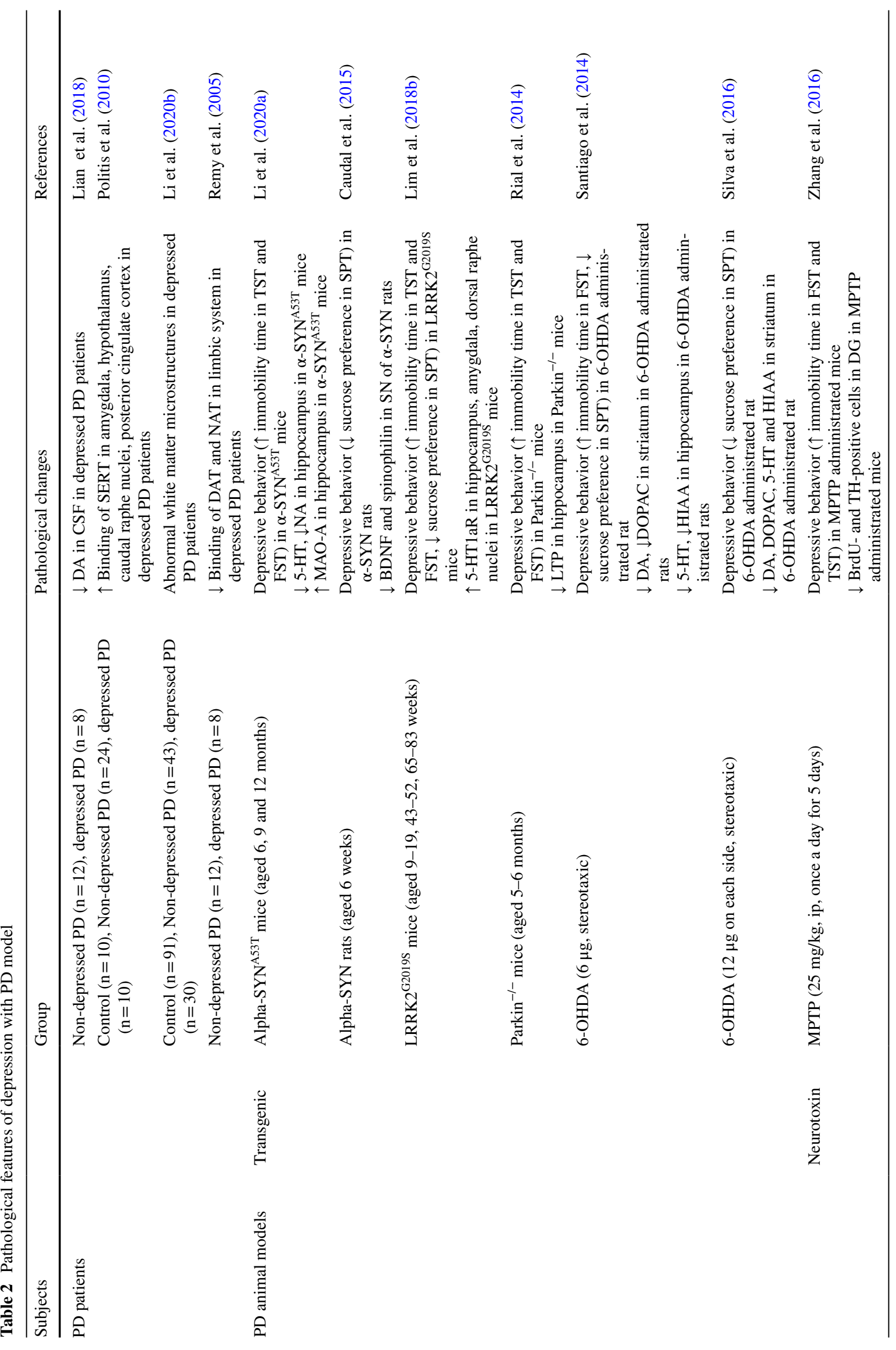


Various evidence demonstrates that PD-related motor and non-motor symptoms are linked to white-matter abnormalities. A whole-brain diffusion tensor imaging study showed impaired frontal and limbic white matter integrity in depressed patients with PD compared to healthy controls/ and non-depressed patients with PD. Depressed patients with PD also showed microstructural damage in the left hippocampal part of the cingulum ( $\mathrm{Li}$ et al. 2020b). In addition, depressed PD patients have abnormal baseline brain activity on MRI compared with non-depressed PD, and the amplitude of low-frequency fluctuations was significantly decreased, which was positively correlated with Hamilton Depression Rating Scale scores (Wen et al. 2013).

Studies have shown that non-motor symptoms of PD are not directly associated with neurodegenerative processes in the substantia nigra pars compacta (Marxreiter et al. 2013). Hippocampal atrophy and disrupted neurogenesis have been observed in genetic animal models and in human postmortem studies of PD (Lim et al. 2018a). In addition, impaired adult neurogenesis in the dentate gyrus of the hippocampus can possibly trigger depression (Jacobs et al. 2000; Lee et al. 2013). Treatment with the antidepressant fluoxetine increases the number of BrdU positive cells in the adult rat hippocampus (Malberg et al. 2000). In fact, medications and other treatments used for depression often enhance adult neurogenesis, and clinical trials using neurogenic compounds to treat major depressive disorder are underway (ClinicalTrials.gov Identifier: NCT01520649, NCT02695472).

\section{Current status and limitations of treatments for depression in PD}

Because the pathophysiology of depression in patients with PD is complex and differs from patients with major depression, the treatment strategy for general mood disorders may not be effective in controlling depressive symptom in patients with PD (Seppi et al. 2019). Clinically, although the majority of PD patients with depression are receiving symptomatic treatment to control their depressive symptoms, up to $50 \%$ of them remain depressed even with treatment (Weintraub et al. 2003). We have no clear guidelines or recommendations on medication for depression in patients with PD. Serotonin reuptake inhibitors and tricyclic antidepressants (TCA) are traditionally the most administered psychiatric medications in PD and somewhat effective in treating depression in PD (Liu et al. 2013). However, their efficacy in PD is still controversial, and other side effects are being raised. In patients with PD and rodent models of PD, fluoxetine has been used as an adjuvant therapy to reduce depressive symptoms and neurodegeneration (Boggio et al. 2005; Zhang et al. 2015b). However, "extrapyramidal" symptoms are associated with fluoxetine treatment; 
fluoxetine was found to exacerbate tremor and dopamine depletion in a rodent pharmacological model of PD (Podurgiel et al. 2015). Amitriptyline, a commonly used TCA, can interfere with the autophagy-mediated removal of protein aggregates, which could increase the risk of neurodegenerative diseases or exacerbate existing neurodegeneration (Kwon et al. 2020). A recent study showing that serotonin $5-\mathrm{HT}_{1 \mathrm{~A}}$ receptor upregulation is accompanied with anxiety/ depression-like behavior in $\mathrm{PD}$ indicates that the 5- $\mathrm{HT}_{1 \mathrm{~A}}$ receptor could be an attractive therapeutic target for PDassociated depression (Lim et al. 2018b). For a better management of depression in PD, further research is needed to evaluate the efficacy and safety of symptomatic treatments and to identify pharmacologic targets based on the specific pathogenesis of PD-associated depression.

\section{Conclusion}

In PD, non-motor symptoms can occur years or decades before motor symptom onset and can increase caregiver burden and significantly reduce the patient's quality of life. Non-motor symptoms in the early/preclinical stages of PD are potentially useful biomarkers for predicting the onset of motor symptoms and diagnosing PD. Moreover, these biomarkers can also identify patients at risk of developing PD or its complications and ultimately lead to neuroprotective and disease control therapy. Although the loss of nigrostriatal dopaminergic neurons is a major neurological deficit in $\mathrm{PD}$, there is accumulating evidence regarding the existence of pathologies for non-motor symptoms beyond the nigrostriatal dopaminergic system. Accordingly, dopaminergic therapy does not affect the olfactory deficit often found in the early stage of PD, and commonly used antidepressants may not be effective in treating depression in PD. As such, the therapeutic management of the non-motor symptoms of PD remains challenging. This review summarizes recent advances in the understanding of the pathology and significance of olfactory dysfunction and depression in PD and therefore provides clues for identifying novel therapeutic targets for controlling PD-associated non-motor symptoms.

\begin{abstract}
Acknowledgements This research was supported by GRRC program of Gyeonggi Province (GRRC-CHA2017-A01, Analysis of Regional Specialized Resources and Operation of Regional Research Service Center), and Basic Science Research Program through the National Research Foundation of Korea (NRF) funded by the Ministry of Education (2020R1I1A1A01074592, NRF-2019R1I1A1A01063630) and the Ministry of Science and ICT (NRF-2018R1A2B6004008).
\end{abstract}

\section{Declarations}

Conflict of interest The authors have no conflicts of interest to disclose.
Open Access This article is licensed under a Creative Commons Attribution 4.0 International License, which permits use, sharing, adaptation, distribution and reproduction in any medium or format, as long as you give appropriate credit to the original author(s) and the source, provide a link to the Creative Commons licence, and indicate if changes were made. The images or other third party material in this article are included in the article's Creative Commons licence, unless indicated otherwise in a credit line to the material. If material is not included in the article's Creative Commons licence and your intended use is not permitted by statutory regulation or exceeds the permitted use, you will need to obtain permission directly from the copyright holder. To view a copy of this licence, visit http://creativecommons.org/licenses/by/4.0/.

\section{References}

Aarsland D, Brønnick K, Alves G, Tysnes OB, Pedersen KF, Ehrt U, Larsen JP (2009) The spectrum of neuropsychiatric symptoms in patients with early untreated Parkinson's disease. J Neurol Neurosurg Psychiatry 80:928-930. https://doi.org/10.1136/jnnp. 2008.166959

Adler CH, Beach TG, Hentz JG, Shill HA, Caviness JN, DriverDunckley E, Sabbagh MN, Sue LI, Jacobson SA, Belden CM, Dugger BN (2014) Low clinical diagnostic accuracy of early vs advanced Parkinson disease: clinicopathologic study. Neurology 83:406-412. https://doi.org/10.1212/WNL.0000000000000641

Alcalay RN, Caccappolo E, Mejia-Santana H, Tang M, Rosado L, Orbe Reilly M, Ruiz D, Ross B, Verbitsky M, Kisselev S, Louis E, Comella C, Colcher A, Jennings D, Nance M, Bressman S, Scott WK, Tanner C, Mickel S, Andrews H, Waters C, Fahn S, Cote L, Frucht S, Ford B, Rezak M, Novak K, Friedman JH, Pfeiffer R, Marsh L, Hiner B, Siderowf A, Payami H, Molho E, Factor S, Ottman R, Clark LN, Marder K (2012) Cognitive performance of GBA mutation carriers with early-onset PD: the CORE-PD study. Neurology 78:1434-1440. https://doi.org/10.1212/WNL. 0b013e318253d54b

Baba T, Takeda A, Kikuchi A, Nishio Y, Hosokai Y, Hirayama K, Hasegawa T, Sugeno N, Suzuki K, Mori E, Takahashi S, Fukuda H, Itoyama Y (2011) Association of olfactory dysfunction and brain. Metabolism in Parkinson's Disease. Mov Disord 26:621628. https://doi.org/10.1002/mds. 23602

Bahuleyan B, Singh S (2012) Olfactory memory impairment in neurodegenerative diseases. J Clin Diagn Res 6:1437-1441. https:// doi.org/10.7860/JCDR/2012/3408.2382

Beach TG, White CL, Hladik CL, Sabbagh MN, Connor DJ, Shill HA, Sue LI, Sasse J, Bachalakuri J, Henry-Watson J, Akiyama H, Adler CH, Consortium APSD (2009) Olfactory bulb alphasynucleinopathy has high specificity and sensitivity for Lewy body disorders. Acta Neuropathol 117:169-174. https://doi.org/ 10.1007/s00401-008-0450-7

Berendse HW, Roos DS, Raijmakers P, Doty RL (2011) Motor and non-motor correlates of olfactory dysfunction in Parkinson's disease. J Neurol Sci 310:21-24. https://doi.org/10.1016/j.jns. 2011.06.020

Berkowicz DA, Trombley PQ (2000) Dopaminergic modulation at the olfactory nerve synapse. Brain Res 855:90-99. https://doi.org/ 10.1016/s0006-8993(99)02342-2

Björkholm C, Monteggia LM (2016) BDNF - a key transducer of antidepressant effects. Neuropharmacology 102:72-79. https://doi. org/10.1016/j.neuropharm.2015.10.034

Blesa J, Phani S, Jackson-Lewis V, Przedborski S (2012) Classic and new animal models of Parkinson's disease. J Biomed Biotechnol 2012:845618. https://doi.org/10.1155/2012/845618 
Boggio PS, Fregni F, Bermpohl F, Mansur CG, Rosa M, Rumi DO, Barbosa ER, Odebrecht Rosa M, Pascual-Leone A, Rigonatti SP, Marcolin MA, Araujo Silva MT (2005) Effect of repetitive TMS and fluoxetine on cognitive function in patients with Parkinson's disease and concurrent depression. Mov Disord 20:1178-1184. https://doi.org/10.1002/mds.20508

Bohnen NI, Gedela S, Herath P, Constantine GM, Moore RY (2008a) Selective hyposmia in Parkinson disease: association with hippocampal dopamine activity. Neurosci Lett 447:12-16. https:// doi.org/10.1016/j.neulet.2008.09.070

Bohnen NI, Gedela S, Kuwabara H, Constantine GM, Mathis CA, Studenski SA, Moore RY (2007) Selective hyposmia and nigrostriatal dopaminergic denervation in Parkinson's disease. J Neurol 254:84-90. https://doi.org/10.1007/s00415-006-0284-y

Bohnen NI, Müller ML, Kotagal V, Koeppe RA, Kilbourn MA, Albin RL, Frey KA (2010) Olfactory dysfunction, central cholinergic integrity and cognitive impairment in Parkinson's disease. Brain 133:1747-1754. https://doi.org/10.1093/brain/awq079

Bohnen NI, Studenski SA, Constantine GM, Moore RY (2008b) Diagnostic performance of clinical motor and non-motor tests of Parkinson disease: a matched case-control study. Eur J Neurol 15:685-691. https://doi.org/10.1111/j.1468-1331.2008.02148.x

Boileau I, Warsh JJ, Guttman M, Saint-Cyr JA, Mccluskey T, Rusjan P, Houle S, Wilson AA, Meyer JH, Kish SJ (2008) Elevated serotonin transporter binding in depressed patients with Parkinson's disease: a preliminary PET study with [11C]DASB. Mov Disord 23:1776-1780. https://doi.org/10.1002/mds.22212

Braak H, Del Tredici K, Rüb U, De Vos RA, Jansen Steur EN, Braak E (2003) Staging of brain pathology related to sporadic Parkinson's disease. Neurobiol Aging 24:197-211. https://doi.org/10.1016/ s0197-4580(02)00065-9

Brandão PRP, Munhoz RP, Grippe TC, Cardoso FEC, De Almeida E, Castro BM, Titze-De-Almeida R, Tomaz C, Tavares MCH (2020) Cognitive impairment in Parkinson's disease: a clinical and pathophysiological overview. J Neurol Sci 419:117177. https://doi.org/10.1016/j.jns.2020.117177

Brodoehl S, Klingner C, Volk GF, Bitter T, Witte OW, Redecker C (2012) Decreased olfactory bulb volume in idiopathic Parkinson's disease detected by 3.0-tesla magnetic resonance imaging. Mov Disord 27:1019-1025. https://doi.org/10.1002/mds.25087

Caudal D, Alvarsson A, Bjorklund A, Svenningsson P (2015) Depressive-like phenotype induced by AAV-mediated overexpression of human alpha-synuclein in midbrain dopaminergic neurons. Exp Neurol 273:243-252. https://doi.org/10.1016/j.expneurol. 2015.09.002

Cecchini MP, Federico A, Zanini A, Mantovani E, Masala C, Tinazzi M, Tamburin S (2019) Olfaction and taste in Parkinson's disease: the association with mild cognitive impairment and the single cognitive domain dysfunction. J Neural Transm (vienna) 126:585-595. https://doi.org/10.1007/s00702-019-01996-z

Chaudhury D, Escanilla O, Linster C (2009) Bulbar acetylcholine enhances neural and perceptual odor discrimination. J Neurosci 29:52-60. https://doi.org/10.1523/JNEUROSCI.4036-08.2009

Cohen-Cory S, Kidane AH, Shirkey NJ, Marshak S (2010) Brainderived neurotrophic factor and the development of structural neuronal connectivity. Dev Neurobiol 70:271-288. https://doi. org/10.1002/dneu.20774

Costa CM, Oliveira GL, Fonseca ACS, Lana RC, Polese JC, Pernambuco AP (2019) Levels of cortisol and neurotrophic factor brain-derived in Parkinson's disease. Neurosci Lett 708:134359. https://doi.org/10.1016/j.neulet.2019.134359

D'souza RD, Vijayaraghavan S (2014) Paying attention to smell: cholinergic signaling in the olfactory bulb. Front Synaptic Neurosci 6:21. https://doi.org/10.3389/fnsyn.2014.00021

Davila NG, Blakemore LJ, Trombley PQ (2003) Dopamine modulates synaptic transmission between rat olfactory bulb neurons in culture. J Neurophysiol 90:395-404. https://doi.org/10.1152/ jn.01058.2002

Deuel LM, Seeberger LC (2020) Complementary therapies in parkinson disease: a review of acupuncture, Tai Chi, Qi Gong, Yoga, and Cannabis. Neurotherapeutics 17:1434-1455. https://doi.org/ 10.1007/s13311-020-00900-y

Domellöf ME, Lundin KF, Edström M, Forsgren L (2017) Olfactory dysfunction and dementia in newly diagnosed patients with Parkinson's disease. Parkinsonism Relat Disord 38:41-47. https:// doi.org/10.1016/j.parkreldis.2017.02.017

Dorsey ER, Constantinescu R, Thompson JP, Biglan KM, Holloway RG, Kieburtz K, Marshall FJ, Ravina BM, Schifitto G, Siderowf A, Tanner CM (2007) Projected number of people with Parkinson disease in the most populous nations, 2005 through 2030. Neurology 68:384-386. https://doi.org/10.1212/01.wnl.00002 47740.47667 .03

Doty RL (2012) Olfaction in Parkinson's disease and related disorders. Neurobiol Dis 46:527-552. https://doi.org/10.1016/j.nbd.2011. 10.026

Doty RL (2017) Olfactory dysfunction in neurodegenerative diseases: is there a common pathological substrate? Lancet Neurol 16:478-488. https://doi.org/10.1016/S1474-4422(17)30123-0

Doty RL, Shaman P, Dann M (1984) Development of the University of Pennsylvania Smell Identification Test: a standardized microencapsulated test of olfactory function. Physiol Behav 32:489-502. https://doi.org/10.1016/0031-9384(84)90269-5

Duchamp-Viret P, Coronas V, Delaleu JC, Moyse E, Duchamp A (1997) Dopaminergic modulation of mitral cell activity in the frog olfactory bulb: a combined radioligand binding-electrophysiological study. Neuroscience 79:203-216. https://doi.org/10.1016/s03064522(96)00646-x

Elhassanien MEM, Bahnasy WS, YaE E-H, Kishk AM, Tomoum MO, Ramadan KM, Allah Ragab OA (2021) Olfactory dysfunction in essential tremor versus tremor dominant Parkinson disease. Clin Neurol Neurosurg 200:106352. https://doi.org/10.1016/j. clineuro.2020.106352

Ephraty L, Porat O, Israeli D, Cohen OS, Tunkel O, Yael S, Hatano Y, Hattori N, Hassin-Baer S (2007) Neuropsychiatric and cognitive features in autosomal-recessive early parkinsonism due to PINK1 mutations. Mov Disord 22:566-569. https://doi.org/10. $1002 /$ mds. 21319

Fearnley JM, Lees AJ (1991) Ageing and Parkinson's disease: substantia nigra regional selectivity. Brain 114(Pt 5):2283-2301. https:// doi.org/10.1093/brain/114.5.2283

Ferraris A, Ialongo T, Passali GC, Pellecchia MT, Brusa L, Laruffa M, Guidubaldi A, Paludetti G, Albanese A, Barone P, Dallapiccola B, Valente EM, Bentivoglio AR (2009) Olfactory dysfunction in Parkinsonism caused by PINK1 mutations. Mov Disord 24:2350-2357. https://doi.org/10.1002/mds.22816

Fleming SM, Tetreault NA, Mulligan CK, Hutson CB, Masliah E, Chesselet MF (2008) Olfactory deficits in mice overexpressing human wildtype alpha-synuclein. Eur J Neurosci 28:247-256. https://doi.org/10.1111/j.1460-9568.2008.06346.x

Frasnelli J, Hummel T (2005) Olfactory dysfunction and daily life. Eur Arch Otorhinolaryngol 262:231-235. https://doi.org/10.1007/ s00405-004-0796-y

Fullard ME, Morley JF, Duda JE (2017) Olfactory dysfunction as an early biomarker in Parkinson's Disease. Neurosci Bull 33:515525. https://doi.org/10.1007/s12264-017-0170-x

Guilloux JP, Douillard-Guilloux G, Kota R, Wang X, Gardier AM, Martinowich K, Tseng GC, Lewis DA, Sibille E (2012) Molecular evidence for BDNF- and GABA-related dysfunctions in the amygdala of female subjects with major depression. Mol Psychiatry 17:1130-1142. https://doi.org/10.1038/mp.2011.113

Gustavsson T, Syvänen S, O'callaghan P, Sehlin D (2020) SPECT imaging of distribution and retention of a brain-penetrating 
bispecific amyloid- $\beta$ antibody in a mouse model of Alzheimer's disease. Transl Neurodegener 9:37. https://doi.org/10.1186/ s40035-020-00214-1

Gutièrrez-Mecinas M, Crespo C, Blasco-Ibáñez JM, Gracia-Llanes FJ, Marqués-Marí AI, Nácher J, Varea E, Martínez-Guijarro FJ (2005) Distribution of D2 dopamine receptor in the olfactory glomeruli of the rat olfactory bulb. Eur J Neurosci 22:1357-1367. https://doi.org/10.1111/j.1460-9568.2005.04328.x

Haehner A, Hummel T, Reichmann H (2011) Olfactory loss in Parkinson's disease. Parkinsons Dis 2011:450939. https://doi.org/ 10.4061/2011/450939

Hakyemez HA, Veyseller B, Ozer F, Ozben S, Bayraktar GI, Gurbuz D, Cetin S, Yildirim YS (2013) Relationship of olfactory function with olfactory bulbus volume, disease duration and Unified Parkinson's disease rating scale scores in patients with early stage of idiopathic Parkinson's disease. J Clin Neurosci 20:1469-1470. https://doi.org/10.1016/j.jocn.2012.11.017

Hawkes CH, Del Tredici K, Braak H (2010) A timeline for Parkinson's disease. Parkinsonism Relat Disord 16:79-84. https://doi.org/10. 1016/j.parkreldis.2009.08.007

He R, Zhao Y, He Y, Zhou Y, Yang J, Zhou X, Zhu L, Liu Z, Xu Q, Sun Q, Tan J, Yan X, Tang B, Guo J (2020) Olfactory dysfunction predicts disease progression in Parkinson's disease: a longitudinal study. Front Neurosci 14:569777. https://doi.org/10.3389/ fnins.2020.569777

Healy DG, Falchi M, O'sullivan SS, Bonifati V, Durr A, Bressman S, Brice A, Aasly J, Zabetian CP, Goldwurm S, Ferreira JJ, Tolosa E, Kay DM, Klein C, Williams DR, Marras C, Lang AE, Wszolek ZK, Berciano J, Schapira AH, Lynch T, Bhatia KP, Gasser T, Lees AJ, Wood NW, International LC (2008) Phenotype, genotype, and worldwide genetic penetrance of LRRK2-associated Parkinson's disease: a case-control study. Lancet Neurol 7:583-590. https://doi.org/10.1016/S1474-4422(08)70117-0

Hsia AY, Vincent JD, Lledo PM (1999) Dopamine depresses synaptic inputs into the olfactory bulb. J Neurophysiol 82:1082-1085. https://doi.org/10.1152/jn.1999.82.2.1082

Huisman E, Uylings HB, Hoogland PV (2004) A 100\% increase of dopaminergic cells in the olfactory bulb may explain hyposmia in Parkinson's disease. Mov Disord 19:687-692. https://doi.org/ 10.1002/mds. 10713

Hustad E, Aasly JO (2020) Clinical and imaging markers of prodromal Parkinson's disease. Front Neurol 11:395. https://doi.org/10. 3389/fneur.2020.00395

Jacobs BL, Van Praag H, Gage FH (2000) Adult brain neurogenesis and psychiatry: a novel theory of depression. Mol Psychiatry 5:262-269. https://doi.org/10.1038/sj.mp.4000712

Jiang L, Zhang H, Wang C, Ming F, Shi X, Yang M (2019) Serum level of brain-derived neurotrophic factor in Parkinson's disease: a meta-analysis. Prog Neuropsychopharmacol Biol Psychiatry 88:168-174. https://doi.org/10.1016/j.pnpbp.2018.07.010

Kasai S, Yoshihara T, Lopatina O, Ishihara K, Higashida H (2017) Selegiline ameliorates depression-like behavior in mice lacking the. Front Behav Neurosci 11:75. https://doi.org/10.3389/fnbeh. 2017.00075

Khan NL, Jain S, Lynch JM, Pavese N, Abou-Sleiman P, Holton JL, Healy DG, Gilks WP, Sweeney MG, Ganguly M, Gibbons V, Gandhi S, Vaughan J, Eunson LH, Katzenschlager R, Gayton J, Lennox G, Revesz T, Nicholl D, Bhatia KP, Quinn N, Brooks D, Lees AJ, Davis MB, Piccini P, Singleton AB, Wood NW (2005) Mutations in the gene LRRK2 encoding dardarin (PARK8) cause familial Parkinson's disease: clinical, pathological, olfactory and functional imaging and genetic data. Brain 128:2786-2796. https://doi.org/10.1093/brain/awh667

Khan NL, Katzenschlager R, Watt H, Bhatia KP, Wood NW, Quinn $\mathrm{N}$, Lees AJ (2004) Olfaction differentiates parkin disease from early-onset parkinsonism and Parkinson disease. Neurology
62:1224-1226. https://doi.org/10.1212/01.wnl.0000118281. 66802.81

Kim JY, Lee WY, Chung EJ, Dhong HJ (2007) Analysis of olfactory function and the depth of olfactory sulcus in patients with Parkinson's disease. Mov Disord 22:1563-1566. https://doi.org/10. 1002/mds. 21490

Kim YH, Lussier S, Rane A, Choi SW, Andersen JK (2011) Inducible dopaminergic glutathione depletion in an $\alpha$-synuclein transgenic mouse model results in age-related olfactory dysfunction. Neuroscience 172:379-386. https://doi.org/10.1016/j.neuroscience. 2010.10.072

Kwon Y, Bang Y, Moon SH, Kim A, Choi HJ (2020) Amitriptyline interferes with autophagy-mediated clearance of protein aggregates via inhibiting autophagosome maturation in neuronal cells. Cell Death Dis 11:874. https://doi.org/10.1038/ s41419-020-03085-6

Lee MM, Reif A, Schmitt AG (2013) Major depression: a role for hippocampal neurogenesis? Curr Top Behav Neurosci 14:153-179. https://doi.org/10.1007/7854_2012_226

Leonhardt B, Tahmasebi R, Jagsch R, Pirker W, Lehrner J (2019) Awareness of olfactory dysfunction in Parkinson's disease. Neuropsychology 33:633-641. https://doi.org/10.1037/neu0000544

Li C, Biswas S, Li X, Dutta AK, Le W (2010) Novel D3 dopamine receptor-preferring agonist D-264: evidence of neuroprotective property in Parkinson's disease animal models induced by 1-methyl-4-phenyl-1,2,3,6-tetrahydropyridine and lactacystin. J Neurosci Res 88:2513-2523. https://doi.org/10.1002/jnr.22405

Li Y, Jiao Q, Du X, Jiang H (2020a) Sirt1/FoxO1-Associated MAO-A upregulation promotes depressive-like behavior in transgenic mice expressing human A53T alpha-Synuclein. ACS Chem Neurosci 11:3838-3848. https://doi.org/10.1021/acschemneu ro.0c00628

Li Z, Liu W, Xiao C, Wang X, Zhang X, Yu M, Hu X, Qian L (2020b) Abnormal white matter microstructures in Parkinson's disease and comorbid depression: a whole-brain diffusion tensor imaging study. Neurosci Lett 735:135238. https://doi.org/10.1016/j. neulet.2020.135238

Lian TH, Guo P, Zuo LJ, Hu Y, Yu SY, Liu L, Jin Z, Yu QJ, Wang RD, Li LX, Piao YS, Zhang W (2018) An investigation on the clinical features and neurochemical changes in Parkinson's disease with depression. Front Psychiatry 9:723. https://doi.org/10.3389/ fpsyt.2018.00723

Lim J, Bang Y, Choi HJ (2018a) Abnormal hippocampal neurogenesis in Parkinson's disease: relevance to a new therapeutic target for depression with Parkinson's disease. Arch Pharm Res 41:943954. https://doi.org/10.1007/s12272-018-1063-x

Lim J, Bang Y, Choi JH, Han A, Kwon MS, Liu KH, Choi HJ (2018b) LRRK2 G2019S induces anxiety/depression-like behavior before the onset of motor dysfunction with 5-HT. J Neurosci 38:16111621. https://doi.org/10.1523/JNEUROSCI.4051-15.2017

Liu J, Dong J, Wang L, Su Y, Yan P, Sun S (2013) Comparative efficacy and acceptability of antidepressants in Parkinson's disease: a network meta-analysis. PLoS ONE 8:e76651. https://doi.org/ 10.1371/journal.pone.0076651

Liu S (2020) Dopaminergic modulation of glomerular circuits in the mouse olfactory bulb. Front Cell Neurosci 14:172. https://doi. org/10.3389/fncel.2020.00172

Liu X, Le W (2020) Profiling non-motor symptoms in monogenic Parkinson's disease. Front Aging Neurosci 12:591183. https://doi. org/10.3389/fnagi.2020.591183

Lois C, Alvarez-Buylla A (1993) Proliferating subventricular zone cells in the adult mammalian forebrain can differentiate into neurons and glia. Proc Natl Acad Sci USA 90:2074-2077. https://doi.org/ 10.1073/pnas.90.5.2074

Lucassen EB, Sterling NW, Lee EY, Chen H, Lewis MM, Kong L, Huang X (2014) History of smoking and olfaction in Parkinson's 
disease. Mov Disord 29:1069-1074. https://doi.org/10.1002/mds. 25912

Ma M, Luo M (2012) Optogenetic activation of basal forebrain cholinergic neurons modulates neuronal excitability and sensory responses in the main olfactory bulb. J Neurosci 32:1010510116. https://doi.org/10.1523/JNEUROSCI.0058-12.2012

Malberg JE, Eisch AJ, Nestler EJ, Duman RS (2000) Chronic antidepressant treatment increases neurogenesis in adult rat hippocampus. J Neurosci 20:9104-9110. https://doi.org/10.1523/JNEUR OSCI.20-24-09104.2000

Malek N, Swallow DM, Grosset KA, Lawton MA, Smith CR, Bajaj NP, Barker RA, Ben-Shlomo Y, Bresner C, Burn DJ, Foltynie T, Morris HR, Williams N, Wood NW, Grosset DG, Investigators P (2016) Olfaction in Parkin single and compound heterozygotes in a cohort of young onset Parkinson's disease patients. Acta Neurol Scand 134:271-276. https://doi.org/10.1111/ane.12538

Mandairon N, Ferretti CJ, Stack CM, Rubin DB, Cleland TA, Linster $\mathrm{C}$ (2006) Cholinergic modulation in the olfactory bulb influences spontaneous olfactory discrimination in adult rats. Eur J Neurosci 24:3234-3244. https://doi.org/10.1111/j.1460-9568.2006. 05212.x

Marchetti B, Tirolo C, L'episcopo F, Caniglia S, Testa N, Smith JA, Pluchino S, Serapide MF (2020) Parkinson's disease, aging and adult neurogenesis: $W n t / \beta$-catenin signalling as the key to unlock the mystery of endogenous brain repair. Aging Cell 19:e13101. https://doi.org/10.1111/acel.13101

Marin C, Laxe S, Langdon C, Berenguer J, Lehrer E, Mariño-Sánchez F, Alobid I, Bernabeu M, Mullol J (2017) Olfactory function in an excitotoxic model for secondary neuronal degeneration: role of dopaminergic interneurons. Neuroscience 364:28-44. https:// doi.org/10.1016/j.neuroscience.2017.09.008

Marxreiter F, Regensburger M, Winkler J (2013) Adult neurogenesis in Parkinson's disease. Cell Mol Life Sci 70:459-473. https://doi. org/10.1007/s00018-012-1062-x

Meyer PM, Strecker K, Kendziorra K, Becker G, Hesse S, Woelpl D, Hensel A, Patt M, Sorger D, Wegner F, Lobsien D, Barthel H, Brust P, Gertz HJ, Sabri O, Schwarz J (2009) Reduced alpha4beta $2 *$-nicotinic acetylcholine receptor binding and its relationship to mild cognitive and depressive symptoms in Parkinson disease. Arch Gen Psychiatry 66:866-877. https://doi.org/ 10.1001/archgenpsychiatry.2009.106

Mueller A, Abolmaali ND, Hakimi AR, Gloeckler T, Herting B, Reichmann H, Hummel T (2005) Olfactory bulb volumes in patients with idiopathic Parkinson's disease a pilot study. J Neural Transm (vienna) 112:1363-1370. https://doi.org/10.1007/ s00702-005-0280-x

Mundinano IC, Hernandez M, Dicaudo C, Ordonez C, Marcilla I, Tunon MT, Luquin MR (2013) Reduced cholinergic olfactory centrifugal inputs in patients with neurodegenerative disorders and MPTP-treated monkeys. Acta Neuropathol 126:411-425. https://doi.org/10.1007/s00401-013-1144-3

Mundiñano IC, Caballero MC, Ordóñez C, Hernandez M, Dicaudo C, Marcilla I, Erro ME, Tuñon MT, Luquin MR (2011) Increased dopaminergic cells and protein aggregates in the olfactory bulb of patients with neurodegenerative disorders. Acta Neuropathol 122:61-74. https://doi.org/10.1007/s00401-011-0830-2

Naoi M, Maruyama W (2009) Functional mechanism of neuroprotection by inhibitors of type B monoamine oxidase in Parkinson's disease. Expert Rev Neurother 9:1233-1250. https://doi.org/10. 1586/ern.09.68

Nicholatos JW, Francisco AB, Bender CA, Yeh T, Lugay FJ, Salazar JE, Glorioso C, Libert S (2018) Nicotine promotes neuron survival and partially protects from Parkinson's disease by suppressing SIRT6. Acta Neuropathol Commun 6:120. https://doi.org/10. 1186/s40478-018-0625-y
Oh YS, Kim JS, Hwang EJ, Lyoo CH (2018) Striatal dopamine uptake and olfactory dysfunction in patients with early Parkinson's disease. Parkinsonism Relat Disord 56:47-51. https://doi.org/10. 1016/j.parkreldis.2018.06.022

Pagano G, Niccolini F, Fusar-Poli P, Politis M (2017) Serotonin transporter in Parkinson's disease: a meta-analysis of positron emission tomography studies. Ann Neurol 81:171-180. https://doi. org/10.1002/ana.24859

Palmer TD, Takahashi J, Gage FH (1997) The adult rat hippocampus contains primordial neural stem cells. Mol Cell Neurosci 8:389-404. https://doi.org/10.1006/mcne.1996.0595

Park H, Poo MM (2013) Neurotrophin regulation of neural circuit development and function. Nat Rev Neurosci 14:7-23. https:// doi.org/10.1038/nrn3379

Paschen L, Schmidt N, Wolff S, Cnyrim C, Van Eimeren T, Zeuner KE, Deuschl G, Witt K (2015) The olfactory bulb volume in patients with idiopathic Parkinson's disease. Eur J Neurol 22:1068-1073. https://doi.org/10.1111/ene.12709

Pearce RK, Hawkes CH, Daniel SE (1995) The anterior olfactory nucleus in Parkinson's disease. Mov Disord 10:283-287. https:// doi.org/10.1002/mds.870100309

Perez-Lloret S, Barrantes FJ (2016) Deficits in cholinergic neurotransmission and their clinical correlates in Parkinson's disease. NPJ Parkinsons Dis 2:16001. https://doi.org/10.1038/ npjparkd.2016.1

Pifl C, Reither H, Del Rey NL, Cavada C, Obeso JA, Blesa J (2017) Early paradoxical increase of dopamine: a neurochemical study of olfactory bulb in asymptomatic and symptomatic MPTP treated monkeys. Front Neuroanat 11:46. https://doi.org/10.3389/ fnana.2017.00046

Podurgiel SJ, Milligan MN, Yohn SE, Purcell LJ, Contreras-Mora HM, Correa M, Salamone JD (2015) Fluoxetine administration exacerbates oral tremor and striatal dopamine depletion in a rodent pharmacological model of Parkinsonism. Neuropsychopharmacology 40:2240-2247. https://doi.org/10.1038/npp.2015.69

Politis M, Wu K, Loane C, Turkheimer FE, Molloy S, Brooks DJ, Piccini P (2010) Depressive symptoms in PD correlate with higher 5-HTT binding in raphe and limbic structures. Neurology 75:1920-1927. https://doi.org/10.1212/WNL.0b013e3181feb2ab

Ponsen MM, Stoffers D, Booij J, Van Eck-Smit BL, Wolters ECH, Berendse HW (2004) Idiopathic hyposmia as a preclinical sign of Parkinson's disease. Ann Neurol 56:173-181. https://doi.org/ 10.1002/ana.20160

Quik M, Di Monte DA (2001) Nicotine administration reduces striatal MPP+ levels in mice. Brain Res 917:219-224. https://doi.org/ 10.1016/s0006-8993(01)02937-7

Quik M, O'leary K, Tanner CM (2008) Nicotine and Parkinson's disease: implications for therapy. Mov Disord 23:1641-1652. https://doi.org/10.1002/mds.21900

Ray Chaudhuri K, Poewe W, Brooks D (2018) Motor and nonmotor complications of levodopa: phenomenology, risk factors, and imaging features. Mov Disord 33:909-919. https://doi.org/10. $1002 /$ mds. 27386

Rebholz H, Braun RJ, Ladage D, Knoll W, Kleber C, Hassel AW (2020) Loss of olfactory function-early indicator for Covid-19, other viral infections and neurodegenerative disorders. Front Neurol 11:569333. https://doi.org/10.3389/fneur.2020.569333

Rektorova I, Srovnalova H, Kubikova R, Prasek J (2008) Striatal dopamine transporter imaging correlates with depressive symptoms and tower of London task performance in Parkinson's disease. Mov Disord 23:1580-1587. https://doi.org/10.1002/mds.22158

Remy P, Doder M, Lees A, Turjanski N, Brooks D (2005) Depression in Parkinson's disease: loss of dopamine and noradrenaline innervation in the limbic system. Brain 128:1314-1322. https:// doi.org/10.1093/brain/awh445 
Rey NL, Wesson DW, Brundin P (2018) The olfactory bulb as the entry site for prion-like propagation in neurodegenerative diseases. Neurobiol Dis 109:226-248. https://doi.org/10.1016/j.nbd. 2016.12.013

Rial D, Castro AA, Machado N, Garcao P, Goncalves FQ, Silva HB, Tome AR, Kofalvi A, Corti O, Raisman-Vozari R, Cunha RA, Prediger RD (2014) Behavioral phenotyping of Parkin-deficient mice: looking for early preclinical features of Parkinson's disease. PLoS ONE 9:e114216. https://doi.org/10.1371/journal. pone. 0114216

Roos DS, Twisk JWR, Raijmakers PGHM, Doty RL, Berendse HW (2019) Hyposmia as a marker of (non-)motor disease severity in Parkinson's disease. J Neural Transm (vienna) 126:1471-1478. https://doi.org/10.1007/s00702-019-02074-0

Santiago RM, Barbiero J, Gradowski RW, Bochen S, Lima MM, Da Cunha C, Andreatini R, Vital MA (2014) Induction of depressive-like behavior by intranigral 6-OHDA is directly correlated with deficits in striatal dopamine and hippocampal serotonin. Behav Brain Res 259:70-77. https://doi.org/10.1016/j.bbr.2013. 10.035

Sauerbier A, Jenner P, Todorova A, Chaudhuri KR (2016) Non motor subtypes and Parkinson's disease. Parkinsonism Relat Disord 22(Suppl 1):S41-46. https://doi.org/10.1016/j.parkreldis.2015. 09.027

Schmidt N, Paschen L, Witt K (2020) Invalid self-assessment of olfactory functioning in Parkinson's disease patients may mislead the neurologist. Parkinsons Dis 2020:7548394. https://doi.org/10. 1155/2020/7548394

Seppi K, Ray Chaudhuri K, Coelho M, Fox SH, Katzenschlager R, Perez Lloret S, Weintraub D, Sampaio C, Committee TCOTPSDUON-MSSGOBOTMDSE-BM (2019) Update on treatments for nonmotor symptoms of Parkinson's disease-an evidencebased medicine review. Mov Disord 34:180-198. https://doi. org/10.1002/mds.27602

Seritan AL, Rienas C, Duong T, Delucchi K, Ostrem JL (2019) Ages at onset of anxiety and depressive disorders in Parkinson's disease. J Neuropsychiatry Clin Neurosci 31:346-352. https://doi.org/10. 1176/appi.neuropsych.18090201

Shill HA, Zhang N, Driver-Dunckley E, Mehta S, Adler CH, Beach TG (2021) Olfaction in neuropathologically defined progressive supranuclear palsy. Mov Disord. https://doi.org/10.1002/mds. 28568

Siderowf A, Newberg A, Chou KL, Lloyd M, Colcher A, Hurtig HI, Stern MB, Doty RL, Mozley PD, Wintering N, Duda JE, Weintraub D, Moberg PJ (2005) [99mTc]TRODAT-1 SPECT imaging correlates with odor identification in early Parkinson disease. Neurology 64:1716-1720. https://doi.org/10.1212/01.WNL. 0000161874.52302.5D

Silva TP, Poli A, Hara DB, Takahashi RN (2016) Time course study of microglial and behavioral alterations induced by 6-hydroxydopamine in rats. Neurosci Lett 622:83-87. https://doi.org/10. 1016/j.neulet.2016.04.049

Struhal W, Presslauer S, Spielberger S, Zimprich A, Auff E, Bruecke T, Poewe W, Ransmayr G, Austrian VPSIT (2014) VPS35 Parkinson's disease phenotype resembles the sporadic disease. J Neural Transm (vienna) 121:755-759. https://doi.org/10.1007/ s00702-014-1179-1

Tani M, Hayakawa H, Yasuda T, Nihira T, Hattori N, Mizuno Y, Mochizuki H (2010) Ectopic expression of $\alpha$-synuclein affects the migration of neural stem cells in mouse subventricular zone. J Neurochem 115:854-863. https://doi.org/10.1111/j.1471-4159. 2010.06727.x

Thaler A, Bregman N, Gurevich T, Shiner T, Dror Y, Zmira O, GanOr Z, Bar-Shira A, Gana-Weisz M, Orr-Urtreger A, Giladi N, Mirelman A (2018) Parkinson's disease phenotype is influenced by the severity of the mutations in the GBA gene. Parkinsonism
Relat Disord 55:45-49. https://doi.org/10.1016/j.parkreldis.2018. 05.009

Tillerson JL, Caudle WM, Parent JM, Gong C, Schallert T, Miller GW (2006) Olfactory discrimination deficits in mice lacking the dopamine transporter or the D2 dopamine receptor. Behav Brain Res 172:97-105. https://doi.org/10.1016/j.bbr.2006.04.025

Todorova A, Jenner P, Ray Chaudhuri K (2014) Non-motor Parkinson's: integral to motor Parkinson's, yet often neglected. Pract Neurol 14:310-322. https://doi.org/10.1136/practneurol-2013-000741

Tong Q, Zhang L, Yuan Y, Jiang S, Zhang R, Xu Q, Ding J, Li D, Zhou X, Zhang K (2015) Reduced plasma serotonin and 5-hydroxyindoleacetic acid levels in Parkinson's disease are associated with nonmotor symptoms. Parkinsonism Relat Disord 21:882-887. https://doi.org/10.1016/j.parkreldis.2015.05.016

Ubeda-Bañon I, Saiz-Sanchez D, De La Rosa-Prieto C, ArgandoñaPalacios L, Garcia-Muñozguren S, Martinez-Marcos A (2010) alpha-Synucleinopathy in the human olfactory system in Parkinson's disease: involvement of calcium-binding protein- and substance P-positive cells. Acta Neuropathol 119:723-735. https:// doi.org/10.1007/s00401-010-0687-9

Ubeda-Bañon I, Saiz-Sanchez D, De La Rosa-Prieto C, Martinez-Mar$\cos$ A (2012) $\alpha$-Synuclein in the olfactory system of a mouse model of Parkinson's disease: correlation with olfactory projections. Brain Struct Funct 217:447-458. https://doi.org/10.1007/ s00429-011-0347-4

Vassilaki M, Christianson TJ, Mielke MM, Geda YE, Kremers WK, Machulda MM, Knopman DS, Petersen RC, Lowe VJ, Jack CR, Roberts RO (2017) Neuroimaging biomarkers and impaired olfaction in cognitively normal individuals. Ann Neurol 81:871882. https://doi.org/10.1002/ana.24960

Videbech P, Ravnkilde B (2004) Hippocampal volume and depression: a meta-analysis of MRI studies. Am J Psychiatry 161:1957-1966. https://doi.org/10.1176/appi.ajp.161.11.1957

Von Coelln R, Thomas B, Savitt JM, Lim KL, Sasaki M, Hess EJ, Dawson VL, Dawson TM (2004) Loss of locus coeruleus neurons and reduced startle in parkin null mice. Proc Natl Acad Sci USA 101:10744-10749. https://doi.org/10.1073/pnas.0401297101

Vroon A, Drukarch B, Bol JG, Cras P, Brevé JJ, Allan SM, Relton JK, Hoogland PV, Van Dam AM (2007) Neuroinflammation in Parkinson's patients and MPTP-treated mice is not restricted to the nigrostriatal system: microgliosis and differential expression of interleukin-1 receptors in the olfactory bulb. Exp Gerontol 42:762-771. https://doi.org/10.1016/j.exger.2007.04.010

Wang J, You H, Liu JF, Ni DF, Zhang ZX, Guan J (2011) Association of olfactory bulb volume and olfactory sulcus depth with olfactory function in patients with Parkinson disease. AJNR Am J Neuroradiol 32:677-681. https://doi.org/10.3174/ajnr.A2350

Wei L, Hu X, Yuan Y, Liu W, Chen H (2018) Abnormal ventral tegmental area-anterior cingulate cortex connectivity in Parkinson's disease with depression. Behav Brain Res 347:132-139. https:// doi.org/10.1016/j.bbr.2018.03.011

Weintraub D, Moberg PJ, Duda JE, Katz IR, Stern MB (2003) Recognition and treatment of depression in Parkinson's disease. J Geriatr Psychiatry Neurol 16:178-183. https://doi.org/10.1177/ 0891988703256053

Wen X, Wu X, Liu J, Li K, Yao L (2013) Abnormal baseline brain activity in non-depressed Parkinson's disease and depressed Parkinson's disease: a resting-state functional magnetic resonance imaging study. PLoS ONE 8:e63691. https://doi.org/10.1371/ journal.pone.0063691

Westermann B, Wattendorf E, Schwerdtfeger U, Husner A, Fuhr P, Gratzl O, Hummel T, Bilecen D, Welge-Lüssen A (2008) Functional imaging of the cerebral olfactory system in patients with Parkinson's disease. J Neurol Neurosurg Psychiatry 79:19-24. https://doi.org/10.1136/jnnp.2006.113860 
Winner B, Geyer M, Couillard-Despres S, Aigner R, Bogdahn U, Aigner L, Kuhn G, Winkler J (2006) Striatal deafferentation increases dopaminergic neurogenesis in the adult olfactory bulb. Exp Neurol 197:113-121. https://doi.org/10.1016/j.expneurol. 2005.08.028

Winner B, Lie DC, Rockenstein E, Aigner R, Aigner L, Masliah E, Kuhn HG, Winkler J (2004) Human wild-type alpha-synuclein impairs neurogenesis. J Neuropathol Exp Neurol 63:1155-1166. https://doi.org/10.1093/jnen/63.11.1155

Winner B, Melrose HL, Zhao C, Hinkle KM, Yue M, Kent C, Braithwaite AT, Ogholikhan S, Aigner R, Winkler J, Farrer MJ, Gage FH (2011) Adult neurogenesis and neurite outgrowth are impaired in LRRK2 G2019S mice. Neurobiol Dis 41:706-716. https://doi.org/10.1016/j.nbd.2010.12.008

Winner B, Rockenstein E, Lie DC, Aigner R, Mante M, Bogdahn U, Couillard-Despres S, Masliah E, Winkler J (2008) Mutant alphasynuclein exacerbates age-related decrease of neurogenesis. Neurobiol Aging 29:913-925. https://doi.org/10.1016/j.neurobiola ging.2006.12.016

Witt M, Bormann K, Gudziol V, Pehlke K, Barth K, Minovi A, Hähner A, Reichmann H, Hummel T (2009) Biopsies of olfactory epithelium in patients with Parkinson's disease. Mov Disord 24:906-914. https://doi.org/10.1002/mds.22464

Yan J, Huang J, Liu A, Wu J, Fan H, Shen M, Lai X, Ma H, Sun W, Yang J, Xu Y (2020) Atorvastatin improves motor function, anxiety and depression by NOX2-mediated autophagy and oxidative stress in MPTP-lesioned mice. Aging (albany NY) 13:831-845. https://doi.org/10.18632/aging.202189

Yang J, Lv DJ, Li LX, Wang YL, Qi D, Chen J, Mao CJ, Wang F, Liu Y, Hu LF, Liu CF (2019) Nicotine improved the olfactory impairment in MPTP-induced mouse model of Parkinson's disease. Neurotoxicology 73:175-182. https://doi.org/10.1016/j. neuro.2019.02.008

Yang T, Nie Z, Shu H, Kuang Y, Chen X, Cheng J, Yu S, Liu H (2020) The role of BDNF on neural plasticity in depression. Front Cell Neurosci 14:82. https://doi.org/10.3389/fncel.2020.00082

Zhang S, Xiao Q, Le W (2015a) Olfactory dysfunction and neurotransmitter disturbance in olfactory bulb of transgenic mice expressing human A53T mutant $\alpha$-synuclein. PLoS ONE 10:e0119928. https://doi.org/10.1371/journal.pone.0119928

Zhang T, Hong J, Di T, Chen L (2016) MPTP impairs dopamine D1 receptor-mediated survival of newborn neurons in ventral hippocampus to cause depressive-like behaviors in adult mice. Front Mol Neurosci 9:101. https://doi.org/10.3389/fnmol.2016.00101

Zhang X, Song D, Gu L, Ren Y, Verkhratsky A, Peng L (2015b) Decrease of gene expression of astrocytic 5-HT2B receptors parallels development of depressive phenotype in a mouse model of Parkinson's disease. Front Cell Neurosci 9:388. https://doi.org/ 10.3389/fncel.2015.00388

Zhou XY, Liu FT, Chen C, Luo SS, Zhao J, Tang YL, Shen B, Yu WB, Zuo CT, Wu JJ, Ding ZT, Wang J, Sun YM (2020) Quality of Life in newly diagnosed patients with parkin-related Parkinson's disease. Front Neurol 11:580910. https://doi.org/10.3389/fneur. 2020.580910

Publisher's Note Springer Nature remains neutral with regard to jurisdictional claims in published maps and institutional affiliations. 